\section{Inverpolly (Knockan Cliff Extension), Western Ross}

The impressive crag of Knockan Cliff runs for just more than a mile along the Ullapool-Elphin road and its southern end has been acquired as an extension to the east side of the Inverpolly National Nature Reserve. This small extension of 36 acres includes one of the most important and frequently visited geological localities in Britain. The west-facing cliff rises about $250 \mathrm{ft}$. above the road and exposes a sequence of rolatively undisturbed Cambrian sediments overlain by Moine schists brought westwards for a distance of several miles by the Moine Thrust-one of the principal structural features of north-western Europe. The seemingly anomalous relationship of the sedimentary and metamorphic rocks has been investigated by geologists for more than a century and the discovery of the true oxplanation (suggosted by Nicol as long ago as 1861) played a vital part in elucidating the structure of the Scottish Highlands and in the development of the science of tectonics.

The area has been purchased by the Nature Conservancy.

\section{Loch Druidibeg (Extension), Inverness-shire}

The extension comprises 1,568 acres of enclosed ground, machair, sand-dunes and sandy shore with a complex of lochs and watercourses in the crofting townships of Stilligarry and Dremisdale, and part of Drimore Farm, South Uist. It is an extension to the Loch Druidibeg National Nature Reserve (hitherto 2,577 acres) which is owned by the Conservancy. The Reserve was established in 1958 to protect the most important breoding ground in Britain of the native grey lag goose, but the ground then acquired covored only half the area used by the geoso which nest by moorland waters in the Reserve and take their broods for rearing to the richer machair lochs of the extension. Throughout the year the geese use the original Reserve for roosting and as a refuge; the oxtension, which is part of a private estate, safoguards their feeding grounds.

In addition to containing this unique population of geese, Loch Druidibog with its extension is a comprehensive Outer Hebridean nature reserve containing moorland, in-bye croftland, machair, dunes and shore. Loch Druidibeg and the neighbouring machair and lochs within the extension constitute one of the finest and most varied samples of this Outer Hebri. dean system remaining in a comparatively unspoilt state. The extonsion has a rich flora and fauna characteristic of the machair grasslands of the Outer Hebrides, which contrast with the very different flora and fauna of Loch Druidibeg, its islands and surrounding moorland. The whole area presents fine research opportunities for studying the ecology and management of grey lag geese and other wildfowl, machair and dune communities, and the physiography of sand-dunes.

The Warden of the Loch Druidibeg Nature Reserve and extension is Mr. M. MacRury. He is a local erofter and his duties include patrolling, fire prevention, prevention of damage to crops by geese, reception of visitors, liaison with crofters and co-operation with the staff of the South Uist Estates.

A nature reservo agreement in respect of the extension was concluded between the Conservancy and the owners of South Uist Estates. The crofters of the Stilligarry and Dremisdale townships and the tenants of Drimore Farm were included in the consultations.

\section{Tentsmuir Point (Extension), Fife}

The extension to the Tentsmuir Point Nature Reserve increases the area from 92 acres to 1,249 acres. The original Reserve doclared in 1954 consisted only of land above the high-water mark. The interest here is chiefly physiographical and botanical, for excoptionally rapid accretion has resulted in a considerable area being won from the sea by natural processes of duno formation and their subsequent stabilization by sand-fixing grasses. Behind the seaward dunes are other dunes showing more advanced stages of plant colonization, and between them are wet slacks, some in process of colonization by alder and birch. The new extension consists mainly of foreshore brought within the Reserve by agreement with the Crown Estate Commissioners; within this area lie the Abertay Sands, a winter roost for wildfowl, including gecse, so that Tentsmuir Point Nature Reserve is now both a nature resorve and a wildfowl refuge in which shooting will be prohibited. The extension also includes an area of 24 acres at the southern end containing samples of alder and willow slacks not represented in the existing reserve. It has been purchased from the Forestry Commission, together with a narrow strip of 12 acres of marshy ground along the western boundary.

\title{
RADIO TELESCOPE ENGINEERING
}

A RECENTLY published articlo by $\mathrm{Mr}$. Jacob Feld* describes some of the engineering problems concerned in the design of radio telescope structures and where these problems differ from those encountered in normal structures. It is thus of value not only to the engineer but also to the scientist, who is able to appreciate more fully the difficulties which have to be overcome in satisfying the somewhat exacting requirementis demanded by this rolativoly new science.

The introductory chapter outlines the new radio astronomy techniquos, its purposes and possibilities,

* Annals of the New York Academy of Seciences. Vol. 93, Article 10 Radio Telescope Structures, By Jacob Feld. Pp. 351-456. (Terv York: New York Academy of Sciences, 1962.) and indicates that requests for reflector surfaces of even greater accuracy are inevitable as the performance of recoiving equipment and amplifiers continues to improve.

The application and adaptation of radar reflectors for radio astronomical purposes is described in the succeeding chapter and the need for new designs emphasized because of the unprecedented size of new structures and the extreme precision required in rates of motion and angular accuracy of control.

Some of the problems associated with wind loading and the differences in approach from normal structural design are dealt with later. It is made clear that the shape of radio telescope roflectors must be maintained under operating wind and temperature 
conditions: the required tolerance being about onetenth of the received wave-length measured from a geometric paraboloid. If part of the reflector is beyond such shape tolerances, the efficiency of the instrument is impaired. The shorter the wave-length of operation, the smaller the tolerances permitted. Thus, for $10-\mathrm{cm}$ wave-lengths the reflector surface may not be out of shape by more than $\pm 1 \mathrm{~cm}$.

The accuracy of pointing and tracking required for these very large masses presents entirely new problems. Whereas optical telescopes are mounted on equatorial axes and it would be desirable for radio telescopes to be similarly mounted, the high resulting torques and the necessity for counterweights that practically double the mass to be moved, increase the costs above the more practical alt-azimuth mounting.

Mechanical power transmissions and gear reduction assemblies are easily available items, but the accuracy of control requires some unusual tolerances in machining, while speeds of motion are so slow that now concepts of bearing designs and frictional values are requirerl.

Two somewhat longer chapters discuss design studies for extremely large telescopes. Brief mention is made of some types of fixed reflectors, while the specifications and design procedure for a $600-\mathrm{ft}$. fully steerable paraboloid reflector are described in greater detail. Mr. Feld summarizes his own com- plete design study for a 600 -ft. instrument and suggests that his findings indicate certain trends which should be further examined and evaluated. In a later chapter, describing some instruments in the United States, mention is made of the $600-\mathrm{ft}$. telescope which has been under construction at the U.S. Navy Observatory at Sugar Grove, West Virginia. Con. struction started early in 1959 and completion at an estimated cost of 79 million dollars was scheduled for 1962. However, the design was completely $\mathbf{r} \in$ vised, resulting in indications pointing to a much larger weight to obtain the desired stiffness and accuracy of shape. Corresponding modifications to underearriage, track and foundations, together with considerable increased cost estimates, would have delayed completion until about 1964. Since publication of this paper, cancellation of the whole project has been announced.

Comparative studies of the design of the $140 \mathrm{ft}$. telescope now being constructed at Green Bank, West Virginia, are described in the latter part of this paper, which concludes with a ehapter discussing a number of fixed types of reflector, planned or already in use.

A full list of references, together with a number of illustrations and drawings, complete an interesting and valuable contribution to the limited reading matter available on radio telescopes. R. F. Touson

\section{GENERAL STUDIES IN TECHNICAL COLLEGES}

GUIDANCE to technical colleges on the selection $\checkmark$ and treatment of the content of 'general studies' for young craftsmen and technicians are contained in a report published by the Ministry of Education*.

The report has been prepared by an advisory committee set up after the publication of the White Paper, "Better Opportunities in Technical Education". The White Paper stated that, when courses were lengthened to the 330 hours a year recommended by the Crowther Committee, the time given to English and general subjects, including physical education, should be increased. The report recalls the "four strands" of the Crowther Report which outlined the wider social purposes of further education. These were to help young workers to find their way successfully about the world both as consumers and citizens, to form standards of moral values by which they can live in the new world in which they find themselves, to continue and develop the pursuits and activities which they have begun at school and to improve their basic education. The report points out that the first need for the students in both the technical and general elements of their course is to develop their communication skills. They must be able to make themselves understood in speech and writing, and, through listening and reading, to understand other people. Success in their technical subjects directly depends on mastery of these skills; they are essential, too, for the student's development as an individual and as a member of society. It is for these reasons that the teaching of English and general studies should be regarded as a single operation.

The report outlines five broad areas of knowledge and experience from which the subject-matter for

* Ministry of Education. General Studies in Technical Colleges. Pp. ii +23. (London: H.M.S.0., 1962.) 2s. net. general studies might be selected. Some of the many suggestions made, under these main headings, are:

(1) The student and the college-nature and organization of the college; the student's place in it; his relations with staff and fellow students.

(2) The student and his job-training facilities; prospects and ambitions; the student's firm; relations on the shop floor; work, wages, costs and profits; health and safety at work.

(3) The student, his home, his family and his friends - the significance of the human family group in society; relations between the sexes; love, courtship marriage.

(4) The student and the wider community-the local community, its history, industry and places of interest; national Government; the welfare state; discipline and the law; present-day economic problems.

(5) The widening of horizons and the development of personal interests - the universe and man's place in it; concepts of space and time; the practice, study and appreciation of the arts; opportunities to practise handicrafts; physical education and recreation.

The report indicates that this broad scheme is not exhaustive nor is it intended to be a syllabus. It is more a storehouse for which topies might be drawn. Not all the subjects would be covered in class time. Many of the activities and interests should spill over into societies and informal groups with a vigorous life of their own.

An appendix suggests how the general lines of approach may be applied to a specific theme. Four 'theme treatments' are given, all of them examples of courses which have been planned and carried out with day-release students. 